\title{
SOCIAL DETERMINANTS OF MATERNAL HEALTH BEHAVIOR AMONG BADUY WOMEN IN LEBAK, BANTEN
}

\author{
Intan Silviana Mustikawati
}

Public Health Program, Universitas Esa Unggul

\begin{abstract}
Background: Maternal health behavior is a set of behaviors that are practiced on the basis of knowledge and awareness, which enables the mother to help herself in the health field. Baduy tribe is a group of indigenous sub-ethnic Sundanese in Lebak District, Banten Province, which implements isolation from the outside world and maintains a traditional way of life, belief, and culture. This study aimed to examine the social factors associatedwith maternal health behavior among Baduy women in Lebak, Banten.

Subjects and Method: This was a cross-sectional study conducted in Kadungketung village, Lebak, Banten, in Januari 2018. A sample of 60 mothers was selected for this study by purposive sampling from Kadungketung village, Lebak, Banten Province. The dependent variable was maternal health behavior. The independent variables were maternal education and belief in traditional healer. The data were collected by questionnaire and interview. The data were analyzed by logistic regression.

Results: $90 \%$ of all mothers under study were $20-34$ years of age, 50\% were primiparous, $100 \%$ were uneducated, $37 \%$ were working as weaver and farmer, $80 \%$ did not have access to health services, 90\% believed intraditional healer, $60 \%$ had poor maternal health behavior, $80 \%$ did not use antenatal care, $90 \%$ gave birth with traditional birth attendence assistance, $60 \%$ did not practice exclusive breastfeeding, $70 \%$ did not weigh their infants at the health service facilities, and $60 \%$ did not use basic immunization service for the infants. Poor health behavior increased with poor maternal education $(\mathrm{OR}=1.45 ; 95 \% \mathrm{CI}=0.5$ to $4.4 ; \mathrm{p}=0.010)$ and belief in traditional healer $(\mathrm{OR}=2.67 ; 95 \% \mathrm{CI}=1.2$ to 5.9 ; $\mathrm{p}<0.001$.
\end{abstract}

Conclusion: Mothers in Kadungketug Village, Banten Province, have poor health behavior due to trust in traditional healers in seeking treatment.

Keywords: education, belief, traditional healer, health behavior, mother

\section{Correspondence:}

Intan Silviana Mustikawati. Public Health Program. Universitas Esa Unggul. Jakarta, 11510, Indonesia. Email: intansilviana@esaunggul.ac.id.

Mobile: 081318501928. 